\title{
The Relationship Between Childhood Trauma, Emotion Regulation Difficulties and Marital Satisfaction in Pregnant Adolescents
}

\author{
Adölesan Gebelerde Çocukluk Çağı Travmaları, Duygu Düzenleme \\ Güçlüğü ve Evlilik Doyumu Arasındaki İlişki
}

Hasan H. Tekin ${ }^{1}$, Özlem Karakuş²

\begin{abstract}
Objective: The objective of this study is to examine the relationship between childhood trauma, emotion regulation difficulties and marital satisfaction in pregnant adolescents. Methods: The model of this study, which is planned as quantitative research, is a relational screening model that aims to determine the presence of change between two or more variables. The universe of the study consisted of pregnant adolescents. The sample of the study consisted of pregnant adolescents (n: 350) who are citizens of The Republic of Turkey and applied to Konya Dr. Faruk Sükan Hospital for Obstetrics and Pediatrics between April 2016-2017. The following forms and scales were used in the study: "Personal Demographic Information Form" developed by the researcher, "Childhood Trauma Scale (CTQ-28)" to determine childhood trauma scores of pregnant adolescents, " Difficulties in Emotion Regulation Scale (DERS)" to determine emotion regulation difficulties scores and "Marriage Life Scale" to determine marital satisfaction scores. The obtained data were analyzed by SPSS 23.0 program. Results: The average age of pregnant adolescents was $17.2 \pm 1$, the marriage age was $16.7 \pm 1$ and the age at first pregnancy was $17.9 \pm 2.0$. It has been found that there is a strong positive relationship between childhood traumas and emotion regulation difficulties in pregnant adolescents. In addition, it has also been concluded that childhood traumas in pregnant adolescents statistically and significantly explains emotional regulation difficulties at a level of $44 \%$ and marital satisfaction at a level of 53\%. Conclusion: It can be concluded that as the neglect and abuse experienced during childhood increases, the emotion regulation difficulties increases and marital satisfaction decreases.
\end{abstract}

Key words: Adolescent pregnancy, childhood trauma, emotion regulation difficulties, marital satisfaction

\section{ÖZET}

Amaç: Bu çalışmanın amacı, adölesan gebelerde çocukluk çağı travmaları, duygu düzenleme güçlüğü ve evlilik doyumu arasındaki ilişkinin incelenmesidir. Yöntem: Nicel araştırma olarak planlanan bu çalışmanın modeli, iki ya da daha çok sayıdaki değişken arasındaki değişim varlığını belirlemeyi amaçlayan iliş̧kisel tarama modelidir. Araştırmanın evrenini adölesan gebeler, örneklemini Nisan 2016-2017 tarihleri arasında Konya Dr. Faruk Sükan Kadın Doğum ve Çocuk Hastalıkları Hastanesine başvuran T.C. vatandaşı adölesan gebeler (n: 350 ) oluşturmuştur. Araştırmacı tarafından geliştirilen "Kişisel Demografik Bilgi Formu", adölesan gebelerin çocukluk çağı travma puanlarını belirlemek için "Çocukluk Çağı Travma Ölçeği (CTQ-28)", duygu düzenleme güçlüğü puanlarını belirlemek için "Duygu Düzenleme Güçlüğü Ölçeği”ve evlilik doyum puanlarını belirlemek için "Evlilik Yaşam Ölçeği” kullanılmıştır. Elde edilen verilen SPSS 23.0 paket

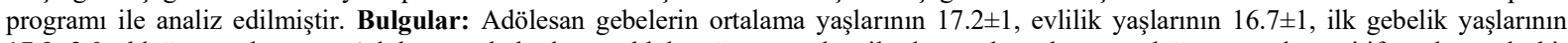
$17.9 \pm 2.0$ olduğu görülmüsstür. Adölesan gebelerde çocukluk çağı travmaları ile duygu düzenleme güçlüğü arasında pozitif yönlü güçlü bir ilişkinin var olduğu görülmüştür. Ayrıca adölesan gebelerde çocukluk çağı travmalarının duygu düzenleme güçlügünü \%44 düzeyinde, evlilik doyumunu ise $\% 53$ düzeyinde istatistiksel olarak anlamlı bir şekilde açıkladığı sonucuna varılmıştır. Sonuç: Çocuk döneminde maruz kalınan ihmal ve istismar arttıkça, ilerleyen dönemlerde duygu düzenleme güçlüğünün artacağ 1 ve evlilik doyumunun azalacağg söylenebilir.

Anahtar kelimeler: Adölesan gebeliği, çocukluk çağı travması, duygu düzenleme güçlüğü, evlilik doyumu

Received Date: 31.01.2019, Accepted Date: 31.07.2019

${ }^{1}$ Department of Social Work, Faculty of Health Science, Necmettin Erbakan University, Konya, Turkey

${ }^{2}$ Department of Social Work, Faculty of Health Science, Selcuk University, Konya, Turkey

*Address for Correspondence / Yazışma Adresi: Hasan Hüseyin Tekin, Department of Social Work, Faculty of Health Science, Necmettin Erbakan University, Konya, Turkey, E-mail: drhhtekin@gmail.com

Tekin HH, Karakus Ö. The Relationship Between Childhood Trauma, Emotion Regulation Difficulties and Marital Satisfaction in Pregnant Adolescents. TJFMPC, 2019;13 (4): 500-507.

DOI: $10.21763 /$ tjfmpc.519969 


\section{INTRODUCTION}

Every child has the right to a healthy life free from violence. However, millions of children around the world are exposed to or witness physical, sexual or emotional abuse every year. Childhood abuse is a universal problem that causes serious effects on the physical and mental health and well-being of the victims and their development. ${ }^{1-3}$ Although child abuse is the same age as humanity, its acceptance as a problem and studies focused on this problem is based on a recent history. ${ }^{4}$ Abuse may be physical, emotional, sexual. While marriages before the age of 18 is also considered sexual abuse, this is common in Turkey. They can marry under the age of 18 and can have children. ${ }^{5}$

Pregnancy is a challenging process in many cases where different women experience different emotional processes. This situation can be seen more in adolescent pregnancies. ${ }^{6}$ The adaptation of the young pregnant woman to the adolescent period, to marriage and to the motherhood role are important and difficult processes. Therefore, it should be kept in mind that the psychological risks of adolescent pregnancy are greater than the medical risks. ${ }^{5-7}$

Adult individuals who have experience and story of neglect and abuse in childhood are involved in a psychological risk group. In addition, these individuals show cowardly, timid, antisocial behavior in their social relations with others. ${ }^{1-8}$ In previous studies, it has been asserted that children develop specific behavioral patterns such as avoidance, rapid response, destructive behaviors, desperation as a result of traumatic experiences and these behaviors are carried to adult life through cognitive schemas. ${ }^{9}$ Empirical studies in the literature on developmental psychology show that childhood abuse affects the acquisition of appropriate emotion regulation strategies and interpersonal skills. $^{10}$

Emotion regulation is the ability of an individual to follow his / her own emotional reactions, to control, evaluate and change these reactions for a purpose and in order to meet this purpose. Emotion regulation involves the initiation of a new emotional response, ie the ability to change the reactions of the existing emotional state under control. It can also reflect a person's own and interpersonal regulation. ${ }^{11-13}$ Repeated traumas such as abuse can cause difficulty in emotion regulation by preventing the child from developing successful emotion regulation and interpersonal skills and by lowering satisfaction in relationships. ${ }^{14,15}$

Gilford and Bengston (1979) describe marital satisfaction as an evaluation of marriage process in general terms, together with positive interactions and negative sentiment of spouses related to marriage. ${ }^{16}$ Neglect and abuse experienced in childhood and difficulty in emotion regulation may cause married couples to experience adaptation and satisfaction problems in their marriages. There are several variables that determine and affect marital satisfaction, and childhood traumas and emotion regulation skills are some of these variables. ${ }^{17,18}$

In this study, we aimed to determine the relationship between childhood trauma and the emotion regulation difficulty and marital satisfaction in pregnant adolescents. According to the facts detailed in the prior paragraphs, we assume that (1) there is a positive correlation between childhood abuse and emotion regulation difficulties in pregnant adolescents; (2) there is a negative correlation between childhood abuse and marital satisfaction in pregnant adolescents; (3) there is a negative correlation between emotion regulation difficulties and marital satisfaction in pregnant adolescents; (4) childhood traumas in pregnant adolescents explain emotion regulation difficulties and marital satisfaction.

\section{METHODS}

The model of this study, which is quantitative research, is the general screening model. In this study, relational screening model was used to determine the relationship between dependent and independent variables. The relational screening model is aimed at determining the presence or degree of interchange between two or more variables. The universe of the study consisted of pregnant adolescents. The sample of the study consisted of pregnant adolescents (n: 350) who are citizens of The Republic of Turkey and applied to Konya Dr. Faruk Sükan Gynecology and Obstetrics Hospital between April 2016-2017. The study continued for one year between April 2016 and April 2017. Criteria for inclusion in the study were "being under 19 years of age, being pregnant, being able to speak and understand Turkish because of the high number of Syrian refugee pregnant women, and being a volunteer". 


\section{Ethical considerations}

The study conformed to scientific and ethical principles outlined in the Declaration of Helsinki. The study was approved by the Local ethics committee. In order to carry out the study, ethics committee approval dated 08.12.2015 and numbered 2015/19 was obtained from KonyaSelçuk University Faculty of Medicine, NonInvasive Clinical Researches Ethics Committee, and application permission was obtained from General Secretary of Konya Public Hospitals Association on 04.04.2016. Verbal information was given to the patients who accepted to participate in the study and their verbal consent was obtained.

\section{Data Collection}

After obtaining the necessary permissions for the research, data was obtained by face-to-face interviews with pregnant adolescents who applied to Konya Dr. Faruk Sükan Gynecology and Obstetrics Hospital. Data was collected via "Personal Demographic Information Form", "Childhood Traumas Questionnaire CTQ-28", “ Difficulties in Emotion Regulation Scale (DERS)" and "Marital Life Scale (MLC)".

Personal Demographic Information Form: In the personal demographic information form prepared by the researcher, there are questions aiming to gather information about the demographic characteristics of pregnant adolescents.

Childhood Traumas Questionnaire CTQ28: The scale, which was developed by Bernstein in 1994, was adapted to Turkish in 1996 and its validity and reliability study was conducted by Şar in 2012.19,20 It is an easy-to-implement measurement tool that is useful in evaluating abuse and neglect before 20 years of age, retrospectively and quantitatively.

Difficulties in Emotion Regulation Scale (DERS): The scale was developed by Gratz and Roemer in 2004. Based on a personal statement, DERS consists of 6 sub-dimensions, such as "Awareness" explaining the lack of awareness for emotional reactions, "Openness" referring the lack of understanding emotional reactions, "Rejection" indicating the refusal of emotional reactions, "Strategies" pointing to limited access to emotion regulation strategies, "Impulse" expressing having difficulties in the control of impulses while experiencing negative emotions and "Objectives" implying having difficulties in goal-oriented behavior while experiencing negative emotions. Turkish adaptation and the validity-reliability study was conducted by Ruganc1 in 2008.21

Marital Life Scale (MLC): The scale, which was developed by Tezer (1996) in order to determine the general satisfaction levels of spouses from the marital relationship, takes values ranging from $1=$ strongly disagree and $5=$ absolutely agree. The scale consists of 10 items and the expressions 2,4 and 5 are scored in reserve. The test-retest reliability coefficient of the scale is .85 ; it is .88 for the Cronbach Alpha male group and .91 for the female group. The results support the reliability of the scale. The highest score that can be taken from the scale is 50 and the lowest score is 10 and the scale does not have a cut-off score. These findings also indicate that the scale is reliable. 22

\section{Statistical Analysis}

20 of the data sets were excluded from the evaluation since they were considered unsuitable for evaluation. The remaining 350 data sets were evaluated with SPSS 23.0 package program. The frequency test was used to determine the means and standard deviations. Pearson product-moment correlation test, in order to test the strength of the linear relationship between two variables and Multiple Regression test were used to predict the value of a variable based on the value of two or more other variables.

\section{RESULTS}

The average age of the pregnant adolescents was $17.2 \pm 1$, the average age of the spouses was $21.2 \pm 2.5$, the average age of marriage was $16.7 \pm 1$, and the age at first pregnancy was $17.9 \pm 2.0$. It was determined that $66.3 \%$ of the pregnant adolescents had official marriage and $33.7 \%$ of them had imam marriage; $30.3 \%$ of the pregnant adolescents married "with prearranged marriage with their own decision", 27.4\% "by making acquaintance, with their own consent", $26.3 \%$ "by eloping", $16 \%$ "with prearranged marriage, with the decision of the family"; $79.6 \%$ of spouses were not relatives, $23.1 \%$ were relatives to each other. According to the educational status of pregnant adolescents, $50.6 \%$ were graduated from primary school, $25.1 \%$ were literate, and $24.3 \%$ 
were high school graduates. When the family types of the adolescents are examined, 57.4\% were found to have extended family, and $42.6 \%$ had a core family.

In our study, while there was a high level of a positive correlation between childhood traumas and emotion regulation difficulties $(r=.66, p$ $<0.05$ ), there was a high level of negative correlation with marital satisfaction $(\mathrm{r}=-.61, \mathrm{p}$
$<0.05)$. In addition, there was a moderately significant negative correlation between emotion regulation difficulties and marital satisfaction $(\mathrm{r}=$ $.55, \mathrm{p}<0.05)$.

While childhood traumas explained emotion regulation difficulties significantly at $44 \%$ level $(\mathrm{R}=.66, \mathrm{R} 2=.44, \mathrm{p}<0.05)$. it explained marital satisfaction significantly at $53 \%$ level $(\mathrm{R}=$ .73, $\mathrm{R} 2 \quad=\quad .53, \quad \mathrm{p} \quad<0,05)$.

\begin{tabular}{|c|c|c|}
\hline $\mathrm{n}: \mathbf{3 5 0}$ & $\overline{\mathbf{x}}$ & Standard Deviation \\
\hline Age & 17.2 & 1.0 \\
\hline Age of Marriage & 16.7 & 1.0 \\
\hline Age at first pregnancy & 17.9 & 2.0 \\
\hline Age of Spouse & 21.2 & 2.5 \\
\hline Educational Background & $\mathbf{N}$ & $\%$ \\
\hline Literate & 88 & 25.1 \\
\hline Primary Education & 177 & 50.6 \\
\hline High School & 85 & 24.3 \\
\hline \multicolumn{3}{|l|}{ Family Type of Adolescent } \\
\hline Core Family & 149 & 42.6 \\
\hline Extended Family & 201 & 57.4 \\
\hline \multicolumn{3}{|l|}{ Wedding Type } \\
\hline Official Marriage & 232 & 66.3 \\
\hline İmam Marriage & 118 & 33.7 \\
\hline \multicolumn{3}{|l|}{ Marriage Type } \\
\hline With His Consent & 96 & 27.4 \\
\hline Prearranged marriage, own decision & 106 & 30.3 \\
\hline Prearranged marriage, family decision & 56 & 16 \\
\hline Eloping & 92 & 26.3 \\
\hline \multicolumn{3}{|l|}{ Affinity with Spouse } \\
\hline Yes & 81 & 23.1 \\
\hline No & 269 & 79.6 \\
\hline
\end{tabular}




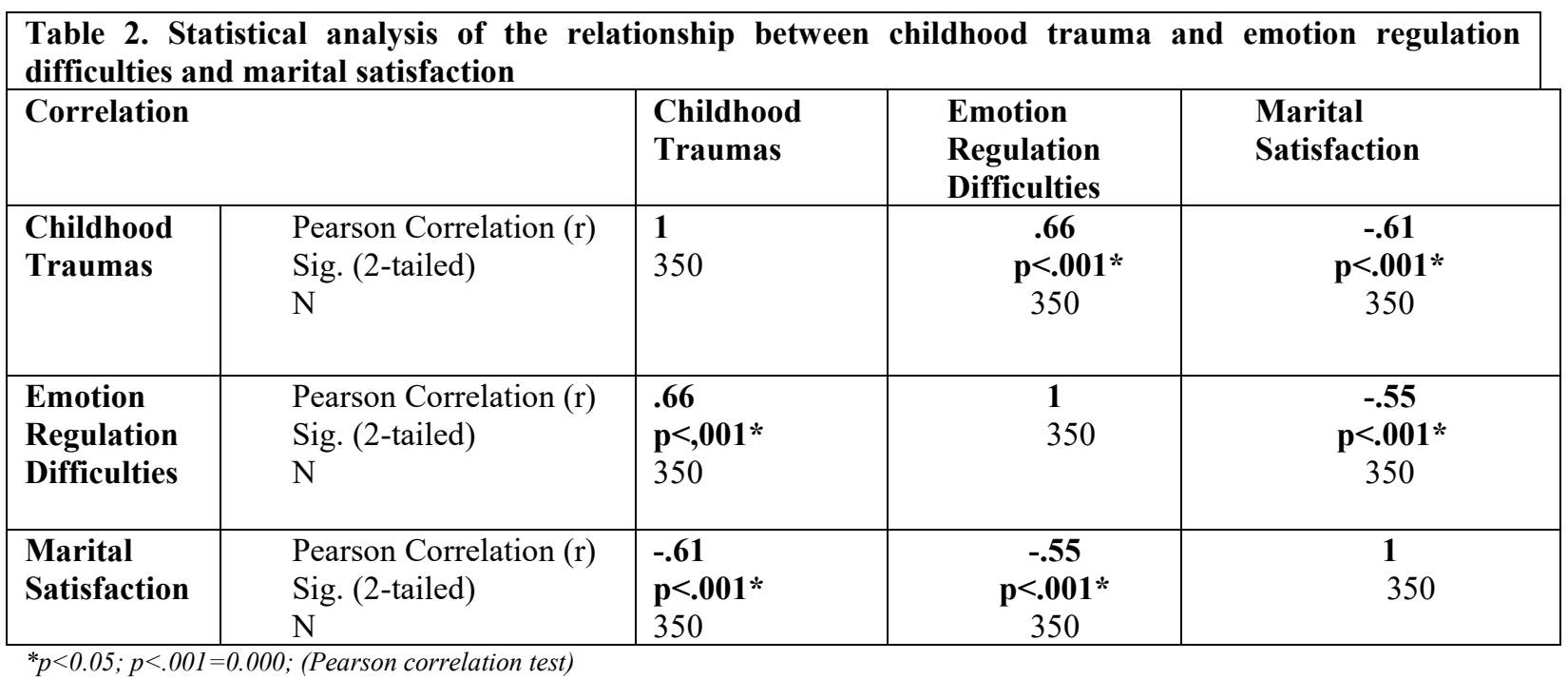

\begin{tabular}{|c|c|c|c|c|c|c|}
\hline Model & $\mathbf{R}$ & $\mathbf{R}^{2}$ & $\mathbf{R}^{2}$ (Adjust) & $\beta$ & $\mathbf{F}$ & $\mathbf{P}$ \\
\hline $\begin{array}{l}\text { Emotion } \\
\text { Regulation } \\
\text { Difficulties }\end{array}$ & .66 & .44 & .44 & .47 & 277.6 & $\mathbf{p}<.001$ * \\
\hline $\begin{array}{l}\text { Marital } \\
\text { Satisfaction }\end{array}$ & .73 & .53 & .53 & -.36 & 198.3 & $\mathbf{p}<.001 *$ \\
\hline
\end{tabular}

${ }^{*} p<0.05 ; p<.001=0.000 ;$ (Regression test)

\section{DISCUSSION}

The aim of this study was to investigate the relationship between childhood traumas and emotion regulation difficulties and marital satisfaction in pregnant adolescents. For this purpose, childhood traumas, emotion regulation difficulties status and marital satisfaction in pregnant adolescents were evaluated with appropriate measurement tools and their current conditions were revealed with the findings. Our results confirmed the hypotheses established at the beginning of the study.

Studies have supported a strong relationship between the traumas experienced in childhood and the emotion regulation difficulties in later stages of life. ${ }^{23-25}$ Young and Widom (2014), in their study investigating the long-term effects of childhood neglect and abuse found that there was a correlation between childhood abuse and emotion regulation process, and that childhood abuse negatively affected the emotion regulation process. ${ }^{26}$ Secrist et al. (2019), in their study, found that childhood trauma, anxiety, dissociation and baseline vagal tone are able to predict $39 \%$ of the variance in nightmare distress and explores the relationship between external emotion Regulation. ${ }^{27}$ Chang et al. (2018) found that survivors who had experienced childhood abuse reported significantly higher scores of emotion regulation difficulties. ${ }^{28}$ Hebert et al. (2018) found that cumulative childhood trauma was associated with higher levels of emotional dysregulation. These results highlight that emotion regulation appears to play a major role in the relations between childhood Trauma. ${ }^{29}$ Dvir et al. (2014) found a complex and bidirectional relationship between childhood trauma exposure and emotional dysregulation. Trauma exposure in childhood is associated with a reduced ability to understand and regulate emotions. ${ }^{30}$

Sexual abuse during childhood may adversely affect the relationships of spouses in the future. In particular, female victims may experience problems such as divorce, separation, conflict and sexual incompatibility later in their lives. ${ }^{18}$ Individuals exposed to emotional abuse may 
experience a decrease in marital quality, excessive attachment to spouses, exposure to spousal violence, decrease in marital satisfaction and harmony in adulthood. ${ }^{17,31}$ Women's emotion regulation skills are effective in ensuring the balance in marriage, and women with this skill can be said to have smoother marriages. ${ }^{32}$ Whisman (2006) found that individuals exposed to childhood trauma experience low marital satisfaction. In the same study, individuals who had been exposed to sexual abuse and rape before the age of 16 had very low marital satisfaction scores. ${ }^{18}$ Nguyen et al. (2017) reveal that there is a strong correlation between child abuse history of couples and present marital satisfaction. Victims of childhood abuse couples' marital satisfaction points are lower than unabused couples. ${ }^{33}$ Nelson and Wampler (2000) found in their study that there was a relationship between exposure to trauma in childhood and low marital satisfaction and the high rate of family break up. ${ }^{17}$ Liu et al. (2018) found that severity of paternal childhood emotional maltreatment was meaningfully associated with paternal marital dissatisfaction, whereas maternal childhood emotional maltreatment was only marginally associated with maternal marital dissatisfaction. ${ }^{34}$

Bloch et al. (2014) found a strong relationship between women's emotion dysregulation and marital satisfaction and asserted that a decrease in the ability to regulate emotions negatively affected the marital relationship. ${ }^{35}$ Mirgain and Cordova (2007) reveal that there is a strong association with emotion regulation and marital satisfaction. ${ }^{36}$ According to Aldao's study (2013) whether the relationship between couples is positive or negative is related to their emotion regulation skills. ${ }^{37}$ Also, Shaid and Kazmi's (2016) studies results indicate that there is a positive correlation between emotional regulation and marital satisfaction. Besides emotional regulation is the predictor of marital satisfaction. ${ }^{38}$ According to the findings of Maneta et al. (2015), it has been observed that childhood traumas in both men and women have a statistically significant negative relationship with the empathic approach and marital satisfaction during adulthood. ${ }^{28}$ The findings and the information in the literature are consistent with the findings of our study.

\section{CONCLUSION}

In the light of the findings of our study, we found that childhood traumas adversely affect emotion regulation skills during adolescence and that there is a positive relationship between these two concepts. We can say that as the traumas experienced during the child period increase, the emotion regulation difficulties will increase.

We also found that childhood traumas had a negative impact on marital experiences and that there is a strong negative relationship between childhood trauma and marital satisfaction. Similarly, we found that there was a strong negative relationship between emotion regulation difficulties and marital satisfaction. We can claim that individuals who have experienced trauma in childhood and who have difficulty in emotion regulation will have problems with marriage life and their marital satisfaction will be lower.

We think that considering the possibility of childhood traumas in young people who have difficulty in emotion regulation, will contribute positively to the treatment process. In addition, we believe that for couples, especially young ones, who have marital satisfaction problems, exposure to childhood trauma and difficulty in emotion regulation should be taken into consideration. As a result, it is very important for children and public health to be aware of possible childhood trauma cases in time and to take preventive interventions besides to intervene in cases that are at risk for adolescent pregnancy. At this point, health professionals, especially family physicians and the ministry of family, work and social services should take responsibility.

\section{REFERENCES}

1. Corby B. Child abuse towards a knowledge base. Open University Press, McGraw Hill Education. England. 2006. p.86-94.

2. Theodore AD, Chang JJ, Runyan DK., Hunder WM, Bangdiwala SJ, Agans R. Epidemiologic features of the physical and sexual maltreatment of children in the carolinas'. Pediatrics. 2005;115(3):331-37. DOI:10.1542/peds.2004-1033

3. Cloitre M, Miranda R, Stovall-McClough KC, Han H. 'Beyond PTSD: Emotion regulation and inter personal problems as predictors of functional impairment in survivors of 
childhood abuse'. Behavior Therapy, 2005;36:119-24.

https://doi.org/10.1016/S0005-7894(05)800607

4. Giardino PA, Lyn MA, Giardino RE. A practical guide to the evaluation of child physical abuse and neglect, Springer, London. 2010.p.3-30.

5. Bulut I. Türkiye'de erken evlilikler. Hacettepe Üniversitesi Sosyal Hizmetler Yüksek Okulu Dergisi, 1991;(1-2-3):77-91

6. Kütük S. Pregnancy in adolescents, risks and problems. Turkish Joutnal of Family Practice. 2012;16:31-34. Doi:10.2399/tahd.12.s031

7. Şen S, Kavlak O. Çocuk gelinler: erken yaş evlilikleri ve adölesan gebeliklere yaklaşım. Aile ve Toplum. 2011;12(7):35-44. http://dergipark.gov.tr/download/articlefile/198037

8. Theoklitou D, Kabitsis N, Kabitsi A. Physical and emotional abuse of primary school children by teachers. Child Abuse\&Neglect, 2012;36(1):6470. DOI:10.1016/j.chiabu.2011.05.007

9. Gomes-Schwartz B, Horowitz JM, Cordelli AP. Child sexual abuse: the initial effects. Thousand Oaks, CA, US: Sage Publications, Inc., 1990. p.205.

10. Sheilds A, Ryan RM, Cicchetti D. Narrative representations of caregivers and emotion dysregulation as predictors of maltreated children's rejection by peers. Developmental Psychology, 2001;37:321-37.

11. Wenar C, Kerig P. Developmental psychopathology: from infancy through adolescence. McGraw Hill Higher Education, 5th Revisededition. 2005. p.123-128.

12. Gross JJ, Thompson RA. Emotion regulation: conceptual foundations. JJ. Gross (Ed.). Handbook of emotion regulation' New York: Guilford Press. 2007. p.3-24.

13. Kring MA, Sloan M.D. Emotion regulation and psychopathology a trans diagnostic approach to etiology and treatment. The Guilford Press, New York. 2009. p.17-19.

14. Cloitre M, Cohen LR, Koenen KC. Treating survivors of childhood abuse: psychotherapy for the interrupted life. New York: Guilford, 2006. p.23-24.

15. Frankel AL, Umemura T, Jacobvitz D, Hazen N. Marital conflict and parental responses to infant negative emotions: relations with emotional regulation. Infant
Behaviour\&Development. 2015;40:73-83. https://doi.org/10.1016/j.infbeh.2015.03.004

16. Gilford R, Bengtson V. Measuring marital satisfaction in three generations: positive and negative dimensions. Journal of Marriage and the Family. 1979;41(12):387-98. http://dx.doi.org/10.2307/351705

17. Nelson BS, Wampler KS. Systemic effects of trauma in clinic couples: an exploratory study of secondary trauma resulting from childhood abuse. Journal of Marital and Family Therapy. 2000;26: 171-184. PMID: 10776604

18. Whisman AM. Childhood trauma and marital outcomes in adulthood. Personal Relationships.2006;12:375-386. https://doi.org/10.1111/j.14756811.2006.00124.x

19. Şar V, Öztürk PE, İkikardeş P. Validity and reliability of the turkish version of childhood trauma questionnaire. Turkiye Klinikleri J Med Sci. 2012;32(4):1054-63. doi: 10.5336/medsci.2011-26947

20. Bernstein PD, Stein JA, Newcomb MD, Walker E, Pogge D, Ahluvalia T, Stokes J, Handelsman L, Mendrano M, Desmond D, Zule W. Development and validation of a brief screening version of the child hood trauma questionnaire. Child Abuse\&Neglect. 2003;27(2):169-90. PMID:12615092

21. Rugancı RN. Bağlanma biçimi, duygulanım düzenleme, psikolojik rahatsızlık ve ilişkisel dünyanın zihinsel yapılanması arasındaki ilişki. Doktora Tezi. Sosyal Bilimler Enstitüs, Ortadoğu Teknik Üniversitesi. Ankara. 2008. p.58-68.

22. Tezer E. Evlilik ilişkisinden sağlanan doyum: Evlilik yaşam ölçeği. Psikolojik Danışma ve Rehberlik Dergisi, 1996;2(7):1-7.

23. Jennissen S, Holl J, Mai H, Wolff S, Barnow S. Emotion dysregulation mediates the relationship between child maltreatment and psychopathology: a structural equation model', Child Abuse\&Neglect. 2016;62:51-62. DOI:10.1016/j.chiabu.2016.10.015

24. Hiraoka R, Crouch LJ, Reo G, Wagner FM, Milner S, Skoeronski JJ. borderline personality features and emotion regulation deficits are asociated with child physical abuse potential, Child Abuse\&Neglect. 2016;52:177-184. DOI:10.1016/j.chiabu.2015.10.023

25. Hebert M, Langevin R, Oussaid E, Cumulative childhood trauma, emotion regulation, dissociation, and behavior problems in school- 
aged sexual abuse victims, Journal of Affective Disorders. 2018;225:306-312. doi: 10.1016/j.jad.2017.08.044.

26. Young JC, Widom CS. Long-term effects of child abuse and neglect on emotion processing in adulthood. Child Abuse\&Neglect. 2014;38(8):1369-81.

DOI:10.1016/j.chiabu.2014.03.008

27. Secrist ME, Dalenberg CJ, Gevirtz R. Contributing factors predicting nightmares in children: Trauma, anxiety, dissociation, and emotion regulation. Psychological Trauma: Theory, Research, Practice, and Policy. 2019. 11(1):114-121. http://dx.doi.org/10.1037/tra0000387

28. Chang C, Kaczkurkin AN, McLean CP, Foa EB. Emotion regulation is associated with PTSD and depression among female adolescent survivors of childhood sexual abuse. Psychological Trauma: Theory, Research, Practice, and Policy. 2018.10(3): 319-326. doi: $10.1037 / \operatorname{tra} 0000306$

29. Hébert M, Langevin R, Oussaïd E. Cumulative childhood trauma, emotion regulation, dissociation, and behavior problems in schoolaged sexual abuse victims. Journal of affective Disorders. 2018, 225:306-312. doi: 10.1016/j.jad.2017.08.044

30. Dvir Y, Ford JD, Hill M, Frazier JA. Childhood maltreatment, emotional dysregulation, andpsychiatric comorbidities. Harvard review of psychiatry. 2014. 22(3): 149-161. doi: 10.1097/HRP.0000000000000014

31. Maneta KE, Cohen S, Schulz SM, Waldinger JR. Linkages between childhood emotional abuse and marital satisfaction: the mediating role of empathic accuracy for hostile emotions. Child Abuse\&Neglect. 2015;44:8-17. doi:10.1016/j.chiabu.2014.07.017

32. Gottman JM, Notarius CI. Decade review: observing marital interaction. Journal of Marriage and the Family. 2000;62:927-47. https://doi.org/10.1111/j.17413737.2000.00927.x

33. Nguyen TP, Karney BR, Bradbury TN. Childhood abuse and later marital outcomes: Do partner characteristics moderate the association?. Journal of family psychology. 2017. 31(1):82-92. doi: 10.1037/fam0000208

34. Liu S, Wang Z, Lu S, Shi J. Dyadic Analysis of childhood emotional maltreatment and marital satisfaction during the transition to parenthood:
The mediating effects of emotion regulation strategies and psychological distress. Journal of Aggression, Maltreatment \& Trauma. 2018:116.

https://doi.org/10.1080/10926771.2018.146638 1

35. Bloch L, Haase CM, Levenson RW. Emotion regulation predicts marital satisfaction: more than a wives' tale. emotion, American Psychological Association. 2014;14(1):130-44. DOI:10.1037/a0034272

36. Mirgain AS, Cordova VJ. Emotion skills and marital health: The association between observed and self-reported emotion skill, intimacy and marital satisfaction. Journal of Social and Clinical Psychology. 2007. 26(9):983-1009.

37. Aldao A. The future of emotion regulation research: Capturing context. Perspectives on Psychological Science.2013. 8(2):55-172. https://doi.org/10.1177/1745691612459518

38. Shahid H, Kazmi SF. Role of emotional regulation in marital satisfaction. International Journal for Social Studies, 2016. 2(4):47-60. 